\title{
Analysis on the Construction Background and Construction Conditions of Hunan DHX Business Logistics Center
}

\author{
Shijun Yuan \\ Hunan Modern Logistics College \\ Changsha, China 410131
}

\author{
Xiangyang Liao \\ Hunan Modern Logistics College \\ Changsha, China 410131
}

\author{
Jianhua Chen* \\ Hunan Modern Logistics College \\ Changsha, China 410131 \\ *Corresponding Author
}

\begin{abstract}
The economy and commercial circulation industry in Hunan DHX have achieved rapid development in recent years, and the construction of business logistics center has been put on the agenda. This paper analyzes the construction background, necessity, demand environment and conditions of the project to provide some suggestions for project construction.
\end{abstract}

Keywords-trade and business; logistics center; construction conditions

\section{INTRODUCTION}

The State Council has approved the establishment of two types of social experimental zone of Changsha-ZhuzhouXiangtan and the gradual implementation of development strategy of $3+5$ city group in Changsha, Zhuzhou and Xiangtan. The status of economic development zone where the project is located has been further established as an important logistics hub, and it will gradually attract wellknown domestic merchants to develop business. After completion of the project, the economic development zone will become a logistics and economic exchange center in Changsha, Zhuzhou and Xiangtan and its surrounding areas, which will be conducive to enhancing the economic radiation capacity and economic driving capacity of the economic development zone.

\section{BACKGROUND OF THE PROJECT}

\section{A. Vigorous Development of Logistics Industry}

As early as early 2009, the State Council issued the Logistics Industry Adjustment and Revitalization Plan, and clearly pointed out the logistics industry was a complex service industry that integrated transportation industry, warehousing industry, freight forwarding industry and information industry, as well as a significant component of the national economy. It covers a wide range of fields, attracts a large number of people, greatly promotes production and stimulates consumption, and plays an important role in promoting industrial restructuring, transforming the pattern of economic development and heightening the competitiveness of the national economy. China has characteristics of rapid development, distinct policy tendency, promising prospect in the development of logistics industry. The logistics industry is a sunrise industry, and logistics major is forward-looking. Logistics integrates the operation concept, management mode and technical means; logistics is the "third profit source", the core of circulation modernization, the new economic growth point of the national economy, an important part of a regional investment environment and an important embodiment of a country's comprehensive strength.

As an emerging industry of national economy, modern logistics industry is developing rapidly all over the world. Its degree of development has become an important symbol to measure the degree of modernization and comprehensive strength of a country or a region. Regardless of the economic integration of Changsha-Zhuzhou-Xiangtan, or regional advantages and urban development, the project area needs to firmly seize this industry development opportunity, rely on its transportation, facilities and industrial advantages, take modern logistics service system as the support and information technology as the means, and cultivate logistics market, so as to realize the socialization, specialization, scale and informatization of logistics. With the guiding spirit of "building a modern logistics system and promoting economic development" as a basic point, based on the strategic goal of building "modern commercial logistics center in central-south Hunan", the logistics industry is vigorously developed to promote the sustained, leaping, coordinated and healthy development of the logistics industry economy.

\section{B. Mushroom Growth of Economy of Project Area}

The project is located in a provincial-level development zone, which is included in the high-tech industrial 
development zone series of Changsha (state), with a planned area of 75 square kilometers.

With the westward migration of municipal government of Changsha, expansion of the city, completion of six bridges, connection of three ring roads, the east and west sides of the Xiangjiang River have been integrated. By means of complete infrastructure, superior natural conditions, good industrial base and broad development hinterland, the park is facing unprecedented opportunities for development. The park has convenient traffic conditions. The West Beijing-Zhuhai Line, Changsha-Changde Expressway, Changsha Belt Expressway, and Shimen-Changsha Railway pass through the territory, and the "six vertical and six horizontal" main roads in the region are interlocked in a network. The Navigation-Power Junction on Xiangjiang River and Jinxia container terminal is from 2 to 3 kilometers away from the park, and are only 30 minutes' driving from Huanghua International Airport. The planned urban light rail traffic in Changsha realizes the seamless connection between the park and Changsha, forming a threedimensional traffic pattern of water, land and air of 'large traffic and large logistics".

\section{Rapid Development of Business and Trade Industry in Changsha}

In recent years, Changsha's economy has continued to grow at a high speed, and the level of urbanization has continued to increase, and the commercial circulation industry has developed rapidly. The scale of commercial circulation industry has been continuously expanded, and its industrial level has been continuously improved, and its system has been continuously improved, and the diversified business entities have basically taken shape. Commercial circulation industry has become an important pillar industry in Changsha.

\section{NECESSITY OF PROJECT CONSTRUCTION}

More than 100 foreign-invested enterprises operate actually in the development zone where the project is located. The implementation of this project will provide comprehensive, fast and humanized business information and life services for logistics investment enterprises, foreigninvested enterprise, investors, institutions and friendly people in the region, help to solve problems in logistics enterprises, foreign investment, production and operation, and daily life as well as provide other assistance and services, and accept the consultation and agent service from logistics enterprises, foreign-invested enterprises and business personnel. The implementation of this project will further optimize the investment environment in the region, improve the efficiency and service quality of government offices, and advance the development of foreign businesses and investment attraction in the economic development zone, which will be of great significance to promote the all-round development of economy in the economic development zone and facilitate the construction of "two types" of society in Changsha-ZhuzhouXiangtan City Group.

\section{A. Developing Economy and Promoting the Construction of Two Types of Society}

The construction of modern business logistics information center in the economic development zone will bring a great opportunity to accelerate the development of logistics industry in the region. The logistics industry is expected to become another pillar industry which has a turnover of more than RMB 20 billion, with rapid development, wide market radiation, huge economic benefits and environmental benefits. The rapid development of engineering machinery logistics industry will drive the rapid advancement of electromechanical industry and other related industries, reduce the proportion of heavy chemical industry with high energy consumption and high pollution, effectively promote the adjustment of regional industrial structure, and strengthen regional economic strength, which will be of great significance to promote the construction of "two types" of society and development of "two types" of industries in Changsha-Zhuzhou-Xiangtan City Group and even Hunan province.

\section{B. Promoting the Development of Social Economy and Related Industries in the Economic Development Zone}

The project integrates the commodity production enterprises, product market information and enterprise demand by constructing the information platform for modern commercial logistics center in the economic development zone: first, integrate information flow, capital flow and logistics into one, and build a information platform for trading, to realize online information release and online transaction and improve transaction speed and efficiency; second, construct an informatization marketing team, strengthen the informatization training for marketing personnel, improve response ability, and provide users with the highest quality service; third, build an information-based transaction service management center to provide users with all-round services and effectively handle relations with customer, so as to realize the connection between different regions in the whole transaction process and all links, greatly reduce transaction costs and improve operators' benefits. It also promotes the economic development in the economic development zone.

\section{ANALYSIS OF PROJECT DEMAND ENVIRONMENT}

\section{A. Foundation Already Possessed by the Economic and Technological Development Zone}

At present, the economic development zone has attracted more than 10 domestic and overseas listed companies from 8 countries and regions including the United States, Canada, Australia, Belgium, Japan, South Korea, Taiwan, and Hong Kong to invest and develop, with the total industrial output value of more than RMB 20 billion. It has gathered more than 100 famous domestic and foreign enterprises, such as Want Want Foods, Jinlong Copper, Bichamp Cutting Technology, America Watts, InBev Xuejin, Outlets, AVIC Landing Gear, Nonferrous Metals Group, AVA Dairy, Ausnutria Dairy, Suntown Technology, Zoomlion Heavy Industry Science \& Technology, Changsha Electric, TRS, Da Bei Nong, and so on

In terms of food and medicine, a food and medicine industry cluster, which takes Want Want Foods, AVA Dairy, Aoyou Food, InBev Xuejin, Tianlong Pharmacy, Kangshou Pharmacy, and Xinhui Pharmacy as the backbone, has been formed. 
In terms of new materials and advanced manufacturing industry, a new material processing and machinery manufacturing industry cluster, led by Jinlong Copper, Suntown Technology, Hunan Nonferrous Holding Group, Botai Technology, Bichamp Cutting Technology, Zoomlion Heavy Industry Science \& Technology, and AVIC Landing Gear, has been formed. In terms of printing and packaging, a printing and packaging industry cluster, represented by provincial press and publication science park, Hunan Daily Press Group, and Changsha printing and packaging industry park, has been formed.

In terms of processing of agricultural industry, a agricultural industry cluster, which takes Taiwan Hsin Tung Yang, Korea CJ, Lingge Wood Industry, Da Bei Nong, Taiwan Dacheng, and Pagoda as the core, has been formed.

In terms of business logistics, a business logistics industry cluster, represented by two strategic investors of Outlets and Helidongsheng, has been formed.

\section{B. Direct Demand of Projects}

With a planned area of over ten thousands mu, Changsha Dahexi Business Logistics City will be built as the top ten commodity wholesale markets with an area of 4 million square meters. After the completion of the project, the Logistics City will become a commodity distribution center of "market display, online trading, electronic payment, and doorto-door delivery". It will attract 100 thousand Hunan businessmen to enter, create more than 100 thousand jobs, and become the largest business logistics market in Central south China. Therefore, a large scale logistics center is needed urgently to support it.

\section{PROJECT CONSTRUCTION CONDITIONS}

\section{A. Topography and Landform}

The area is dominated by hilly terrain with low elevation, which will not bring adverse impact on project construction and operation.

\section{B. Geology and Hydrology}

This area includes hills, downland, basins, valleys and plains, and they are staggered. The whole terrain inclines from north to west, south and southeast. Most of the soil parent materials are quartz sand and Quaternary red earth, with purple shale and plate shale between them. The engineering geology is in a good condition.

The hydrological conditions at the site are relatively simple and will not adversely affect the project construction and operation.

\section{Seismic Data}

According to Seismic Ground Motion Parameter Zonation Map of China (GB18306- 2001), the ground motion peak acceleration in this area is less than $0.05 \mathrm{~g}$, and the period of seismic response spectrum is $0.35 \mathrm{~s}$. That is to say, the seismic basic intensity in this area is 6, which belongs to a weak seismic area, and seismic fortification can be ignored

\section{Traffic Conditions}

This area has excellent regional transportation and complete infrastructure. It is located in the beautiful and fertile valley plain of central Hunan, both sides of lower reaches of the Xiangjiang River, and the intersection of Beijing to Guangzhou and Shanghai to Chongqing (BeijingGuangzhou Economic Corridor and Yangtze River Economic Zone), it is also the only way for the coastal economy to spread to and radiate the western region. 319 national highway and Changsha-Changde expressway cross the territory of county, and Changsha-Xiangyin highway, a provincial highway, passes through the east of county. The Leigao road, Leifeng road and Gaoqiao road connect with the provincial highway, national highway and expressway. Beijing-Guangzhou railway and Shimen-Changsha railway cross the territory and there are also many passenger stations. Xiangjiang River flows from the south to the north and flows through the county for 58 kilometers. There are thousands of tons of ports in the territory.

\section{E. Climatic Conditions}

The project is located in the subtropical climate zone, which is obviously affected by the monsoon. The climate is characterized by large temperature changes in spring, more rain in early summer, high temperature and drought in autumn and less frost days in winter.

The temperature is lowest in January with an average temperature of $4.4^{\circ} \mathrm{C}$, and is highest in July with an average temperature of $30^{\circ} \mathrm{C}$. Except for Heimifeng, the frost-free period in other areas is about 270-300 days in the whole year.

In this region, the mean annual sunshine duration is 1610.5 hours, the annual precipitation is about $1370 \mathrm{~mm}$, and the mean annual precipitation day reaches 146 days, among which, the precipitation will reach more than $200 \mathrm{~mm}$ per month in May and June, and it will reach more than $100 \mathrm{~mm}$ per month in July and August. The climatic condition on the site is good and will not adversely affect the project construction.

\section{F. Water and Power Supply Conditions}

The site of project is located at the town centre of economic development zone, where the water and electricity pipe network and other urban infrastructures will be supported completely. The water for engineering construction and operation after the logistics center is completely have absolute guarantee, and the good power supply condition can fully meet the demands of this project engineering.

\section{G. Communication Conditions}

The rapid development of postal service and telecom in the urban area of economic development zone has achieved digital transmission and digital programme-controlled exchange. China Telecom, China Mobile, China Unicom and other communication network agencies have provided the fast, high-quality and convenient information and communication guarantee for this county.

\section{H. Building Materials and Transportation Conditions}

Building stones: the limestone reserves around the city of economic development zone are abundant and the quality is 
good, which can be used as the building stones, and the transportation distance is relatively short.

Sand and gravel pack: the quality of sand in the nearby building stones of sand field is relatively good, which can be purchased nearby.

Lime: the nearby limestone is rich in storage, and there are many lime plants. The quality of the produced lime is good and can be purchased nearby.

Cement: there are many cement plants around the economic development zone and surrounding counties and cities, which can fully meet the demand of project construction.

Steel products: it can be purchased from surrounding construction material markets of the counties and in Changsha or allocated and transported directly from the manufacturer. It is convenient to supply.

Other building materials: the professional construction materials market in the economic development zone and surrounding areas can meet the supply.

\section{CONCLUSION}

The construction project of logistics center of Changsha DHX business logistics city conforms to the development trend of Changsha modern commerce and trade circulation service and logistics industry, and is in line with the overall development plan of the economic development zone, meeting the demand of industries, such as industry, commerce and trade circulation and agriculture, for logistics services in Changsha and economic development zone. It is conducive to improving the service level of the trade service industry and the logistics industry, promoting regional economic development; it facilitates the intensive use of land resources, reduces the pressure of roads, environment and energy; it makes for the government departments to manage logistics market and improve service levels; it promotes the development of regional modern service industries and increases employment opportunities.

\section{REFERENCES}

[1] Zhao Miao. The Cumulative Causal Effect Analysis on Building an International Business Center City and Logistics Industry Development [J]. Journal of Beijing Institute of Finance and Commerce Management. 2012 (06)

[2] Chang Qiao. Trade Logistics to Develop in Depth and Breadth [J]. China Logistics \& Purchasing. 2017 (05)

[3] Peng Xiaojing, Song Guoxue. The Countermeasures of Constructing the Important Base of Modern Commercial Logistics in Hebei [J]. Journal of Hebei University (Philosophy and Social Science). 2017 (03) 